\title{
The Influence of Foreign Institutional Ownership on the Stock Liquidity in China Based on Data Analysis
}

\author{
Zitang Shen \\ Chinese Academy of Finance and Development, Central University of Finance and Economics, Beijing, 100089, China
}

\begin{abstract}
The negative impact of foreign participation on the liquidity of companies that allow a high degree of foreign institutional ownership has been widely documented. This article provides a unique environment for the limited participation of qualified foreign institutional investors (QFIIs) in China's A-share market, and examines how these factors affect stock liquidity in emerging markets. Contrary to previous findings, the participation of foreign investors has helped increase the liquidity of affected stocks by facilitating increased trading activity. Improved liquidity in small businesses is more important than large ones. The findings of this article are the endogenous robustness and the impact on the stock market, industry impact, and possible impact on the stock exchange. In addition, when analyzing sub-samples of QFII companies, QFII's liquidity improvement effect is even stronger. This article aims to through data analysis on the stock liquidity provide Chinese stock market with management suggestions.
\end{abstract}

\section{INTRODUCTION}

From the view of globalization, the general trend of financial liberalization and capital flows have become an inevitable tendency and China is increasingly integrated with the global economy. There are different arguments about the relationship between the foreign institutional investor ownership and stock liquidity. Firstly, foreign institutional investors usually have information advantages. They can help investors form rational investment concept and then improve market efficiency[9]. Additionally, the introduction of foreign investment can improve the quality of information disclosure of a company, which can reduce the potential risk or the transactional cost. Hence, it influences the liquidity positively[5]. Secondly, the presence of major shareholders can reduce the number of publicly traded shares, thereby lowering stock liquidity by cutting down trading activity[7]. Moreover, these talented foreign institutional investors can serve as information traders. As a result, severe information asymmetry will be brought, influencing the liquidity negatively[8].

With the help of the panel regression model containing firm and time fixed effect, this paper focuses on the influence of foreign institutional participation on stock market liquidity under China's QFII scheme. Meanwhile, the author also tries to use different factors to estimate market liquidity (illiquidity ratio and trading volume) and to carry out the robustness test, and discuss the heterogeneity in different firm size.

\section{LITERATURE REVIEW AND HYPOTHESIS DEVELOPMENT}

Studies have shown that foreign investors as informed traders may improve the liquidity of stocks.

First of all, as informed traders, the identity of the information advantage is easy to cause herding effect in the market. Seasholes points out that foreign investors possess more resources, more experience in international capital markets and more effective investment strategies[1]. Based on QFII's heavy holdings in the mainland stock market, Sun and Lin found that the capital performance of QFII reflects the strong adaptability of foreign investors to China's economic development and better grasp the development cycle of the industry[2]. This significant investment advantage is likely to attract more capital and the attention of investors, and increase the liquidity. Then the herding effect appears. The higher the proportion of foreign ownership is, the more attention will be paid to the stock of the listed company by other investors. With the increase of the amount of investment and the number of transactions, the bid-ask spread of the corresponding stock decreases, increasing the liquidity and weakening the volatility of the stock price.

Second, foreign investors, as informed traders, increase the competition and information efficiency in the market. Grossman pointed out that the competition and monopoly behavior of informed traders in a market with asymmetric information will have an impact on the integration of private information into the stock price[3]. Subrahmanyam believes that not only foreign investors but also relatives of foreign company managers and some

angela@cas-harbour.org 
institutional investors are informed traders, and their competitive behavior will make this information included in the stock price[4]. Therefore, the information efficiency of the stock raises, so as the liquidity of the stock. By analyzing a non-competitive market model, Subrahmanyam concludes that the liquidity is nonmonotonous in terms of the number of informed traders and the accuracy of information, and the competition between the informed traders will lead to the increase of the information into trading, thus bringing the increase of stock liquidity[4].

In addition, qualified foreign institutional investors can trigger a significant improvement in the information disclosure of the company, and the improvement of the quality of information disclosure can reduce the potential risks and transaction costs, and improve the liquidity of stocks[5]. Stulz believes that when foreign investors invest in domestic stocks to become shareholders of listed companies, they have a stronger and more professional ability to supervise the company than small and mediumsized retail investors[6]. Hence, it will effectively improve the level of corporate governance of domestic listed companies, give a rise to the level and quality of information disclosure to a greater extent, and reduce the degree of information asymmetry of stocks. Therefore, the liquidity of stocks finally enhance.

Ding believes that the information advantage of foreign institutional investors will be particularly critical in developing countries, especially in China, because the problems of information transparency and information asymmetry in China have always been very serious. So the positive effect is more significant in China[7]. Amihud and Mendelson believes that after the introduction of foreign investors, domestic listed companies can enrich the equity structure and allocate certain risks to foreign investors, and the diversification of shareholders increases the liquidity of stocks[8].

Take all the above into consideration, we propose the following two assumptions: firstly, the higher the QFII shareholding ratio is, the greater the stock trading volume is, and the better the stock liquidity of the company is. Secondly, Other conditions remain unchanged, the smaller the size of the company is, the more obvious the role of QFII in promoting stock liquidity is.

\section{MEASUREMENT OF VARIABLES AND MODEL SPECIFICATION}

Due to the inherent nature and multidimensional nature of liquidity, a single measure cannot capture all of its characteristics. A commonly used measure in the relevant literature is liquidity, which is also employed in this article. The selection of control variables included in panel data regression is mainly based on literature.

To measure inventory liquidity, you first need to define inventory liquidity from the perspective of price impact. Here, the liquidity indicator Illiq proposed by Amihud is used instead of the liquidity of the stock.

$$
\text { Illiq }_{i, t}=\frac{\mid \text { Return }_{i, t} \mid}{\text { Volume }_{i, t}}
$$

Return $_{i, t}$ refers to the stock's average quarterly return in time $t$, and Volume $_{i, t}$ is quarterly trading volume. The higher the Amihud ratio Illiq is, the higher the stock's illiquidity, the lower the stock's liquidity.

TV represents the trading volume that we has used in the calculation of Illiquidity ratio. Intuitively the higher the trading volume is, the higher the stock's liquidity is.

Previous researches have shown that company size, stock price volatility, stock price and turnover are related to liquidity. Smaller trading stocks are more expensive for company size because there is less relevant information about these companies[10]. In addition, volatility increases the inventory risk of market makers and the risk of unintentional short-term speculative trading [11]. Moreover, former researches have shown that this spread may be non-linearly related to price. Therefore, the standard practice is to use the natural logarithm of the stock price [12].

In our panel data regression, we control these by including the stock return volatility (VOL) estimated by the standard deviation of daily stock returns. Meanwhile, the company size (SIZE) is measured by the company's book value and the natural logarithm of the stock price. Impact (LNP) and turnover (TO) were used as explanatory variables. We also control domestic institutional investor (DI) ownership by including the percentage ownership of the five largest domestic institutions (ie, open-end funds, securities, insurance, trust companies, and pension funds).

Finally, we include two controlling variables of the Chinese stock market: state-owned enterprise (SOE) virtual (STATE) and non-tradable shares ratio (NT). The Chinese stock market is characterized by the dominance of state-owned enterprises. From previous researches, it can be concluded that whether a company is state-owned or not, the liquidity of stocks is affected by facts [3]. Therefore, if the enterprise is a state-owned enterprise, the SOE dummy variable is controlled as a proxy for political connections by defining a dummy variable with a value of 1. We use the company's new Taiwan dollar to control the share allocation structure. Many explanatory variables are provided only on a quarterly basis; we measure these variables at the beginning of each quarter (represented by the subscript $\mathrm{t}-1$ in regression). The remaining variables are measured as the average over each quarter (indicated by subscript $t$ in the regression). 
TABLE I. SUMMARY STATISTICS

Table 1

\begin{tabular}{|c|c|c|c|c|c|c|c|c|c|c|}
\hline Variable & Observations & Mean & SD & $\begin{array}{c}95 \text { th } \\
\text { Percentile }\end{array}$ & $\begin{array}{c}75 \text { th } \\
\text { Percentile }\end{array}$ & Median & $\begin{array}{c}\text { 25th } \\
\text { Percentile }\end{array}$ & $\begin{array}{c}5 \text { th } \\
\text { Percentile }\end{array}$ & Skewness & Kurtosis \\
\hline Illiquidity (Illiq) & 130343 & -21.919 & 1.383 & -19.447 & -21.170 & -22.011 & -22.799 & -23.979 & 0.674 & 5.268 \\
\hline $\begin{array}{l}\text { Trading volume } \\
\text { (TV, shares, } \\
\text { billions per share) }\end{array}$ & 130345 & 0.137 & 0.300 & 0.475 & 0.144 & 0.063 & 0.027 & 0.006 & 14.570 & 448.299 \\
\hline QFII ownership & 10723 & 0.016 & 0.028 & 0.048 & 0.017 & 0.008 & 0.004 & 0.001 & 7.447 & 93.226 \\
\hline $\begin{array}{l}\text { Domestic } \\
\text { ownership (DI) }\end{array}$ & 149401 & 0.037 & 0.067 & 0.163 & 0.047 & 0.010 & 0.000 & 0.000 & 3.969 & 30.163 \\
\hline $\begin{array}{l}\text { Size (SIZE, yuan, } \\
\text { billions) }\end{array}$ & 147320 & 6.681 & 52.673 & 15.371 & 2.945 & 1.252 & 0.566 & 0.059 & 23.671 & 691.057 \\
\hline Volatility (VOL) & 130135 & 0.032 & 0.045 & 0.055 & 0.036 & 0.028 & 0.021 & 0.015 & 82.714 & 12410.075 \\
\hline $\begin{array}{l}\text { Turnover rate (TO, } \\
\text { per quarter) }\end{array}$ & 72922 & 3.157 & 3.796 & 8.854 & 3.844 & 2.163 & 1.151 & 0.439 & 5.810 & 71.814 \\
\hline $\begin{array}{l}\text { Share price }(\mathrm{P}, \\
\text { Yuan) }\end{array}$ & 130345 & 15.116 & 15.787 & 40.730 & 18.100 & 10.670 & 6.510 & 3.380 & 7.561 & 184.280 \\
\hline $\begin{array}{l}\text { Nontradable share } \\
\text { ratio (NT) }\end{array}$ & 131568 & 9.990 & 26.579 & 82.412 & 0.000 & 0.000 & 0.000 & 0.000 & 2.507 & 7.845 \\
\hline $\begin{array}{l}\text { Leverage ratio } \\
\text { (LEV) }\end{array}$ & 117014 & 0.561 & 6.818 & 0.837 & 0.623 & 0.459 & 0.284 & 0.099 & 156.724 & 27606.089 \\
\hline Age (AGE, years) & 147415 & 15.316 & 6.011 & 25.000 & 19.000 & 15.000 & 11.000 & 6.000 & 0.887 & 7.137 \\
\hline $\begin{array}{l}\text { Return on assets } \\
\text { (ROA, \% per } \\
\text { quarter) }\end{array}$ & 147315 & 3.214 & 40.416 & 13.367 & 5.017 & 2.034 & 0.547 & -2.557 & 71.271 & 28328.257 \\
\hline $\begin{array}{l}\text { Herfindahl } 10 \\
\text { index }(\mathrm{CO})\end{array}$ & 131571 & 0.176 & 0.132 & 0.434 & 0.242 & 0.143 & 0.079 & 0.032 & 1.539 & 6.423 \\
\hline
\end{tabular}

TABLE II. CORRELATION COEFFICIENT

Table 2 (a)

\begin{tabular}{|c|c|c|c|c|c|c|c|c|c|c|c|c|c|}
\hline & Illiq & TV & QFII & DI & SIZE & VOL & TO & $\mathrm{P}$ & NT & LEV & AGE & ROA & $\mathrm{CO}$ \\
\hline Illiq & 1 & & & & & & & & & & & & \\
\hline TV & $-0.5018^{*}$ & 1 & & & & & & & & & & & \\
\hline QFII & $-0.0519^{*}$ & $0.0341^{*}$ & 1 & & & & & & & & & & \\
\hline DI & $-0.1866^{*}$ & $0.0965^{*}$ & $0.1270^{*}$ & 1 & & & & & & & & & \\
\hline SIZE & $-0.1930^{*}$ & $0.2307^{*}$ & 0.000600 & $0.0448^{*}$ & 1 & & & & & & & & \\
\hline VOL & $0.0277^{*}$ & $0.0856^{*}$ & $-0.0391^{*}$ & $-0.0177^{*}$ & $-0.0273^{*}$ & 1 & & & & & & & \\
\hline TO & $-0.1322 *$ & $0.1651^{*}$ & $-0.1194^{*}$ & $-0.1193^{*}$ & $-0.0636^{*}$ & $0.3744^{*}$ & 1 & & & & & & \\
\hline$P$ & $-0.2500^{*}$ & $0.1823^{*}$ & -0.0126 & $0.1937^{*}$ & $-0.0220^{*}$ & $0.0866^{*}$ & $0.2622^{*}$ & 1 & & & & & \\
\hline NT & $0.4991^{*}$ & $-0.1284^{*}$ & $0.1428^{*}$ & $-0.0967^{*}$ & $-0.0400^{*}$ & $-0.0132^{*}$ & $-0.1296^{*}$ & $-0.1677^{*}$ & 1 & & & & \\
\hline LEV & $0.0145^{*}$ & -0.00130 & $0.1633^{*}$ & -0.00720 & 0.00160 & -0.000400 & $-0.0175^{*}$ & $-0.0199^{*}$ & $0.0132^{*}$ & 1 & & & \\
\hline AGE & $-0.2527^{*}$ & $0.0818^{*}$ & 0.0141 & $0.0145^{*}$ & 0.00580 & $-0.0539^{*}$ & $-0.0854^{*}$ & $-0.0537^{*}$ & $-0.3192^{*}$ & $0.0146^{*}$ & 1 & & \\
\hline ROA & $-0.0271^{*}$ & $0.0105^{*}$ & $0.0320^{*}$ & $0.0119^{*}$ & -0.00270 & 0.00670 & 0.00750 & $0.0540^{*}$ & $0.0406^{*}$ & $-0.1649^{*}$ & $-0.0172^{*}$ & 1 & \\
\hline $\mathrm{CO}$ & $0.0839^{*}$ & $-0.0390^{*}$ & $-0.1179^{*}$ & $-0.0581^{*}$ & $0.0692^{*}$ & $0.0106^{*}$ & $-0.0412^{*}$ & $0.0314^{*}$ & $0.3308^{*}$ & $-0.0102^{*}$ & $-0.2428^{*}$ & $0.0288^{*}$ & 1 \\
\hline
\end{tabular}

TABLE III. PRELIMINARY ANALYSIS OF THE RELATIONSHIP BETWEEN LIQUIDITY AND QFII

\begin{tabular}{lccc}
\hline variables & $\begin{array}{c}\text { Mean for QFII firms } \\
\text { Observations=10642 }\end{array}$ & $\begin{array}{c}\text { Mean for non-QFII firms } \\
\text { Observations=119701 }\end{array}$ & -Value \\
\hline Illiquidity & -22.475 & -21.870 & 0.000 \\
$\begin{array}{l}\text { Trading Volume } \\
\text { (in Billions, per day) }\end{array}$ & 18.356 & 17.856 & 0.000 \\
\hline
\end{tabular}

Equation (2) specifies the panel data model for examining the relationship between the QFII participation and stock market liquidity. The dependent variable measuring liquidity is the illiquidity ratio and trading volume.

We estimate the following main panel regression for firm $\mathrm{i}$ and time $\mathrm{t}$ :

$$
\begin{aligned}
& \mathrm{LIQ}_{\mathrm{i}, \mathrm{t}}=\alpha_{0}+\mathrm{a}_{1} \mathrm{QFII}_{\mathrm{i}, \mathrm{t}-1}+\alpha_{2} \mathrm{DI}_{\mathrm{i}, \mathrm{t}-1}+\alpha_{3} \mathrm{SIZE}_{\mathrm{i}, \mathrm{t}-1}+\alpha_{4} \mathrm{STATE}_{\mathrm{i}, \mathrm{t}-1}+\alpha_{5} \mathrm{LEV}_{\mathrm{i}, \mathrm{t}-1}+\alpha_{6} \mathrm{VOL}_{\mathrm{i}, \mathrm{t}}+\alpha_{7} \mathrm{LNP}_{\mathrm{i}, \mathrm{t}}+ \\
& \alpha_{8} \mathrm{TO}_{\mathrm{i}, \mathrm{t}}+\alpha_{9} \mathrm{NT}_{\mathrm{i}, \mathrm{t}-1}+\sum_{\mathrm{q}} \beta_{\mathrm{q}} \mathrm{D}_{\mathrm{q}}+\varepsilon_{\mathrm{i}, \mathrm{t}}
\end{aligned}
$$


In this equation LIQ equals Illiq or TV, and QFII represents the percentage ownership by qualified foreign institutional investors. Due to the high skewness and kurtosis, we transform all the dependent variables by taking the natural logarithm. The control variables to be considered are the domestic institutional ownership (DI), the firm size (SIZE), the SOE dummy (STATE), the leverage ratio (LEV), the stock return volatility (VOL), the natural logarithm of the share price (LNP), the turnover rate (TO), and the non-tradable share ratio (NT). The quarterly time dummies (D) documents common shocks and potential time trends. For each liquidity measure, we run two panel regressions: the first regression used QFII ownership as explanatory variables, while the second regression used QFII ownership and domestic institutional ownership as explanatory variables (all regressions included the remaining control variables). If QFII ownership is positively correlated with liquidity, the QFII coefficient then indicate that liquidity is negative and television is positive.

\section{DATA}

\subsection{Data sources and data filtering}

The data on the QFII ownership are our independent variable is from CSMAR. The dependent variables measuring the liquidity of stocks are from REESET. The Illiq and TV are quarterly averaged across all trading days for each stock in each year.

There are several control variables in this paper. According to Agarwal (2007), the high turnover may reflect belief dispersion induced by information differences among investors [11]. The turnover ratio is calculated by dividing the total trading volume in a year by the outstanding shares. Volatility is calculated based on the standard deviation of quarterly average daily stock returns. Besides, according to Chordia, Roll, and Subrahmanyam (2001), volatility increases the risk of market makers' inventory and the risk of unintentional short-term speculative trading [11]. Furthermore, it is suggested that a firm's capital structure can affect the degree of information disclosure. Therefore, capital structure can be related to market liquidity through information channels. Leverage is measured by a company's total debt divided by its total assets. The age of a company is measured by the current year minus the established year. We also control domestic institutional investor (DI) ownership by including ownership percentages for the five largest domestic institutions. Return on assets is measured as net profit divided by total assets. Finally, China's stock market is characterized by the dominance of state-owned enterprises, and previous researches find that whether a company is a state-owned enterprise will affect the liquidity of the stock because of its connection with the government [3]. Hence, we define the dummy variable (if the enterprise is state-owned) and set the value of the dummy variable to 1 to control the state-owned enterprise dummy variable as a proxy for political connections.

\subsection{Descriptive statistics and preliminary analysis}

Table 1 shows that, on average, Qualified Foreign Institutional Investors (QFIIs) hold $1.6 \%$ of the company's issued shares, while domestic institutions each hold approximately $3.7 \%$. The average illiquidity ratio is about -21.919. In terms of trading volume, the mean is 0.137 million shares per day.

Table 2 is the correlation coefficient. We can have a preliminary idea that Illiq is negatively correlated to QFII ownership, and TV is positively correlated to QFII ownership.

In order to visually reflect the dynamic relationship between liquidity and ownership, the total value of QFII holdings each quarter and the two average quarterly liquidity indicators Illiq and TV are plotted, as shown in figure 1. The right vertical axis shows QFII participation, and the left vertical axis shows liquidity during the sample period (2004Q3-2019Q1). The intuitive evidence in figure 1 shows that over time, there is a negative correlation between QFII holdings and market liquidity. Figure 2 intuitively shows the positive correlation between QFII holdings and trading volumes. We perform preliminary univariate tests on the two liquidity measures, Illiq, TV and the two trading activity measures for two subsamples of firms: those with QFIIs and those without (non-QFII firms).

We assume that, if the QFII participation increases liquidity, different (average) values of the various measures for the two groups of firms are expected. This conclusion can be drawn from table 3 . And all differences are statistically significant at the $5 \%$ level.

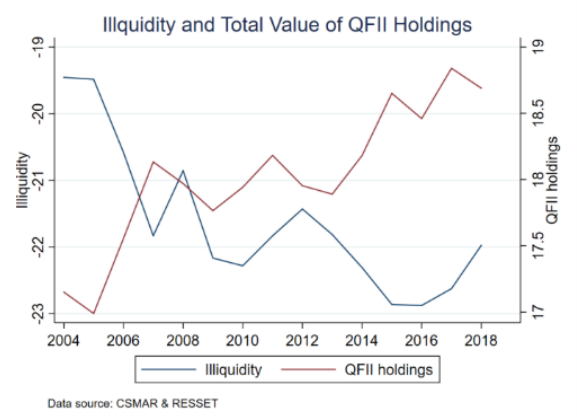

Figure 1. Illiquidity and Total Value of QFII Holdings

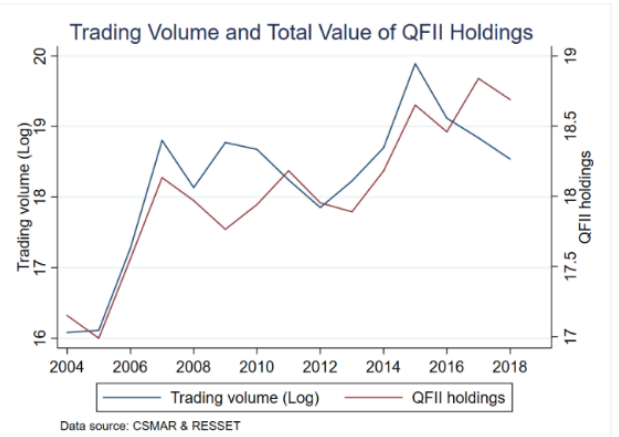

Figure 2. Trading Volume and Total Value of QFII Holdings 


\section{Empirical results}

TABLE IV. QFII RELATIONSHIP WITH LIQUIDITY

\begin{tabular}{|c|c|c|c|c|}
\hline \multirow{3}{*}{$\begin{array}{l}\text { Independent } \\
\text { variables }\end{array}$} & \multicolumn{4}{|c|}{ Dependent variables } \\
\hline & (1) & $(2)$ & (3) & (4) \\
\hline & Illiq & Illiq & TV & TV \\
\hline \multirow[t]{2}{*}{$Q F I I_{i, t}$} & $-0.0111 *$ & $-0.0113^{*}$ & $0.0105^{*}$ & $0.0103 *$ \\
\hline & $(0.0063)$ & $(0.0063)$ & $(0.0055)$ & $(0.0054)$ \\
\hline \multirow[t]{2}{*}{$D I_{i, t}$} & & $0.0030 * * *$ & & $0.0027 * * *$ \\
\hline & & $(0.0009)$ & & $(0.0009)$ \\
\hline \multirow[t]{2}{*}{$T O_{i, t}$} & $-0.1402 * * *$ & $-0.1391 * * *$ & $0.2186^{* * *}$ & $0.2196 * * *$ \\
\hline & $(0.0044)$ & $(0.0044)$ & $(0.0057)$ & $(0.0058)$ \\
\hline \multirow{2}{*}{$S I Z E_{i, t-1}$} & $-0.6729 * * *$ & $-0.6710 * * *$ & $0.5760 * * *$ & $0.5777 * * *$ \\
\hline & $(0.0176)$ & $(0.0176)$ & $(0.0157)$ & $(0.0158)$ \\
\hline \multirow[t]{2}{*}{$L E V_{i, t-1}$} & $-1.0718 * * *$ & $-1.0714 * * *$ & $1.0483 * * *$ & $1.0487 * * *$ \\
\hline & $(0.0670)$ & $(0.0670)$ & $(0.0632)$ & $(0.0632)$ \\
\hline \multirow[t]{2}{*}{$V O L_{i, t}$} & $1.5607 * * *$ & $1.5538 * * *$ & $0.8061 * *$ & $0.7998 * *$ \\
\hline & $(0.4898)$ & $(0.4877)$ & $(0.3694)$ & $(0.3678)$ \\
\hline \multirow[t]{2}{*}{$N T_{i, t-1}$} & $0.0220 * * *$ & $0.0219 * * *$ & $-0.0220 * * *$ & $-0.0221 * * *$ \\
\hline & $(0.0004)$ & $(0.0004)$ & $(0.0004)$ & $(0.0004)$ \\
\hline \multirow[t]{2}{*}{$L N P_{i, t-1}$} & $-0.7480 * * *$ & $-0.7597 * * *$ & $0.7270 * * *$ & $0.7164 * * *$ \\
\hline & $(0.0137)$ & $(0.0141)$ & $(0.0135)$ & $(0.0141)$ \\
\hline State & Yes & Yes & Yes & Yes \\
\hline$N$ & 57865 & 57865 & 57865 & 57865 \\
\hline $\operatorname{adj} . R^{2}$ & 0.695 & 0.695 & 0.730 & 0.730 \\
\hline$F$ & 3703.9643 & 3224.0997 & 4289.7284 & 3768.3899 \\
\hline
\end{tabular}

Standard errors in parentheses $(* \mathrm{p}<0.1, * * \mathrm{p}<0.05, * * * \mathrm{p}<0.01)$

\subsection{Foreign institutional ownership and stock market liquidity}

Table 4 shows that the increased foreign institutional ownership is associated with a lower illiquidity ratio. That is to say, the increased foreign institutional ownership is associated with higher stock market liquidity.

TABLE V. FIXED EFFECT MODEL

\begin{tabular}{lcccc}
\hline & \multicolumn{4}{c}{ Dependent variables } \\
\cline { 2 - 4 } Independent & $(1)$ & $(2)$ & $(3)$ & $(4)$ \\
variables & Illiq & Illiq & TV & TV \\
\hline$Q F I I_{i, t-1}$ & $-0.0091^{* * *}$ & $-0.0077^{* *}$ & $0.0145^{* * *}$ & $0.0126^{* *}$ \\
$D I_{i, t}$ & $(0.0032)$ & $(0.0032)$ & $(0.0053)$ & $(0.0052)$ \\
& & $-0.8629^{* * *}$ & & $1.1495^{* * *}$ \\
$S I Z E_{i, t-1}$ & & $(0.0396)$ & & $(0.0914)$ \\
& $-0.3233^{* * *}$ & $-0.3211^{* * *}$ & $0.2910^{* * *}$ & $0.2881^{* * *}$ \\
$L E V_{i, t-1}$ & $(0.0045)$ & $(0.0045)$ & $(0.0115)$ & $(0.0114)$ \\
$V O L_{i, t}$ & $-0.5500^{* * *}$ & $-0.5377^{* * *}$ & $0.6351^{* * *}$ & $0.6187^{* * *}$ \\
$N T_{i, t-1}$ & $(0.0208)$ & $(0.0207)$ & $(0.0459)$ & $(0.0450)$ \\
& $1.1389^{* * *}$ & $1.1616^{* * *}$ & $0.8658^{* *}$ & $0.8355^{* *}$ \\
$L N P_{i, t}$ & $(0.0628)$ & $(0.0626)$ & $(0.3445)$ & $(0.3353)$ \\
$T O_{i, t}$ & $0.0081^{* * *}$ & $0.0082^{* * *}$ & $-0.0105 * * *$ & $-0.0106^{* * *}$ \\
State & $(0.0003)$ & $(0.0003)$ & $(0.0005)$ & $(0.0005)$ \\
Time dummy & $-0.5528^{* * *}$ & $-0.5155^{* * *}$ & $0.5168^{* * *}$ & $0.4672^{* * *}$ \\
\hline$N$ & $(0.0053)$ & $(0.0056)$ & $(0.0114)$ & $(0.0120)$ \\
adj. $R^{2}$ & $-0.1057^{* * *}$ & $-0.1091^{* * *}$ & $0.1649 * * *$ & $0.1694^{* * *}$ \\
$F$ & $(0.0011)$ & $(0.0011)$ & $(0.0041)$ & $(0.0042)$ \\
& Yes & Yes & Yes & Yes \\
& Yes & Yes & Yes & Yes \\
\hline
\end{tabular}


Standard errors in parentheses $(* \mathrm{p}<0.1, * * \mathrm{p}<0.05, * * * \mathrm{p}<0.01)$

The next two regressions show that the foreign institutional ownership is significantly and positively related to trading volume.

\subsection{Fixed effect model}

Unobservable time-invariant factors may simultaneously affect both the left-hand side and the right-hand side of the regression in Equation (2). As a result, regression is affected by the bias of missing variables. Therefore, we estimated the regression of fixed-time effects in an attempt to control possible missing variables. We report the results of firm fixed-effect regression in table 5 .

It is found that when applying the fixed effects model, the positive correlation between QFII ownership and liquidity indicators does not change. That strengthens our previous finding that the positive relationship between the foreign institutional ownership and the liquidity attributes to the increased trading volume.

TABLE VI. DIFFERENT FIRM SIZE

\begin{tabular}{|c|c|c|c|c|}
\hline \multirow{4}{*}{$\begin{array}{l}\text { Independent } \\
\text { variables }\end{array}$} & \multicolumn{4}{|c|}{ Dependent variables } \\
\hline & \multicolumn{2}{|c|}{ Large firms } & \multicolumn{2}{|c|}{ Small firms } \\
\hline & $(1)$ & (2) & $(3)$ & (4) \\
\hline & Illiq & TV & Illiq & TV \\
\hline \multirow[t]{2}{*}{$Q F I I_{i, t-1}$} & -0.0022 & 0.0068 & $-0.0106 * *$ & $0.0202 * * *$ \\
\hline & $(0.0059)$ & $(0.0062)$ & $(0.0052)$ & $(0.0044)$ \\
\hline \multirow[t]{2}{*}{$D I_{i, t-1}$} & $-0.6926^{* * *}$ & $0.9246^{* * *}$ & $-0.4560 * * *$ & $0.9676 * * *$ \\
\hline & $(0.1181)$ & $(0.1197)$ & $(0.1164)$ & $(0.1179)$ \\
\hline \multirow[t]{2}{*}{$S I Z E_{i, t-1}$} & $-0.3514 * * *$ & $0.3114 * * *$ & $-0.2750 * * *$ & $0.2677 * * *$ \\
\hline & $(0.0192)$ & $(0.0189)$ & $(0.0181)$ & $(0.0174)$ \\
\hline \multirow{2}{*}{$L E V_{i, t}$} & $-0.2907 * * *$ & $0.3530 * * *$ & $-0.6550 * * *$ & $0.7860 * * *$ \\
\hline & $(0.0712)$ & $(0.0731)$ & $(0.0568)$ & $(0.0600)$ \\
\hline \multirow[t]{2}{*}{$V O L_{i, t}$} & 1.3563 & 0.4012 & $1.1775^{* * *}$ & $1.0405 * * *$ \\
\hline & $(0.8703)$ & $(0.5039)$ & $(0.3743)$ & $(0.3212)$ \\
\hline \multirow[t]{2}{*}{$N T_{i, t-1}$} & $0.0057 * * *$ & $-0.0090 * * *$ & $0.0086^{* * *}$ & $-0.0103 * * *$ \\
\hline & $(0.0007)$ & $(0.0007)$ & $(0.0007)$ & $(0.0006)$ \\
\hline \multirow[t]{2}{*}{$L N P_{i, t}$} & $-0.5693 * * *$ & $0.5203^{* * *}$ & $-0.4798 * * *$ & $0.4087 * * *$ \\
\hline & $(0.0174)$ & $(0.0182)$ & $(0.0159)$ & $(0.0155)$ \\
\hline \multirow[t]{2}{*}{$T O_{i, t}$} & $-0.1383 * * *$ & $0.2177 * * *$ & $-0.0978 * * *$ & $0.1524 * * *$ \\
\hline & $(0.0081)$ & $(0.0108)$ & $(0.0037)$ & $(0.0043)$ \\
\hline State & Yes & Yes & Yes & Yes \\
\hline Time dummy & Yes & Yes & Yes & Yes \\
\hline$N$ & 32814 & 32814 & 31840 & 31840 \\
\hline $\operatorname{adj} . R^{2}$ & 0.783 & 0.799 & 0.769 & 0.801 \\
\hline$F$ & 1610.4196 & 1840.2160 & 1514.0860 & 1554.2132 \\
\hline
\end{tabular}

Standard errors in parentheses $(* \mathrm{p}<0.1, * * \mathrm{p}<0.05, * * * \mathrm{p}<0.01)$

\subsection{Different firm size}

We investigate whether the positive relationship between QFII engagement and liquidity is widespread across large and small companies. Therefore, we performed panel regression analysis on the model in equation (1) by dividing the total sample into two sub-samples of stocks listed by different company sizes. Table 6 shows the negative (positive) coefficient of Illiq (television) QFII ownership, and its importance is limited to small companies. We found that the magnitude of the Illiq and TV coefficient estimates for small companies $(-0.0106$ and 0.0202 , respectively) are similar to the full sample estimates; however, the impact of QFII ownership on large companies is negligible. One possible reason for this difference is better regulation of large companies. As a result, the impact of QFII ownership is less pronounced compared to smaller companies.

\section{ENDOGENEITY OF FOREIGN INSTIRUTIONAL OF OWNERSHIP}

The preference of QFII to the stocks with high liquidity may also play a role in the positive correlation of QFII ownership. That may lead to the reverse causality. Therefore, in this section, we will study endogeneity to reduce this concern about causality and endogeneity.

\subsection{Endogeneity test}

The paper performs an endogeneity test developed by $\mathrm{Wu}$ (1973) and Hausman (1978) to examine whether the QFII ownership or the illiquidity variables are endogenous. Two-stage least squares (2SLS) regressions is conducted, where the first-stage regression includes the same control variables as in the main regression (Table 3 ), together with a set of new explanatory variables. The following additional explanatory variables are used in the first-stage 
regression: the return on assets(ROA), the firm age (AGE), and an ownership concentration index, the Herfindahl 10 index (OC). The Herfindahl 10 index measures the degree of ownership dispersion in the top 10 shareholder structure. We also include industry fixed effect dummies (IND) that are equal to 1 if the firm operates in a given industry. The industry classification is released by the CSRC, and the data are provided in the CCER database. There are 13 different industries at the level of classification used in equation 2. The first-stage regression is as follows.

$$
\begin{aligned}
\text { QFII }_{\mathrm{i}, \mathrm{t}}=\omega_{0}+\omega_{1} \mathrm{LIQ}_{\mathrm{i}, \mathrm{t}-1}+\omega_{2} \mathrm{DI}_{\mathrm{i}, \mathrm{t}-1}+\omega_{3} \mathrm{SIZE}_{\mathrm{i}, \mathrm{t}-1}+\omega_{4} \mathrm{STATE}_{\mathrm{i}, \mathrm{t}-1}+\omega_{5} \mathrm{LEV}_{\mathrm{i}, \mathrm{t}-1}+\omega_{6} \mathrm{VOL}_{\mathrm{i}, \mathrm{t}}+\omega_{7} \mathrm{LNP}_{\mathrm{i}, \mathrm{t}}+\omega_{8} \mathrm{TO}_{\mathrm{i}, \mathrm{t}}+\omega_{9} \mathrm{NT}_{\mathrm{i}, \mathrm{t}-} \\
{ }_{1}+\Sigma_{\mathrm{q}} \beta_{\mathrm{q}} \mathrm{D}_{\mathrm{q}}+\omega_{10} \mathrm{ROA}_{\mathrm{i}, \mathrm{t}-1}+\omega_{11} \mathrm{AGE}_{\mathrm{i}, \mathrm{t}-1}+\omega_{12} \mathrm{OC}_{\mathrm{i}, \mathrm{t}-1}+\Sigma_{\mathrm{m}} \pi_{\mathrm{m}} \operatorname{IND}_{\mathrm{m}, \mathrm{i}, \mathrm{t}-1}+\mu_{\mathrm{i}, \mathrm{t}}
\end{aligned}
$$

Table 7 shows the 2SLS regression analysis. QFII ownership is the dependent variable of the first stage of the estimation described in the first stage, while the second stage estimates the main regression model (Table 3) baseline model by replacing the actual QFII ownership with the lag value of the remaining R_QFII of QFII. First stage estimation. The Driscoll-Kraay standard error reported in parentheses is robust to internal company residuals over time and the correlation between companies and different companies in the same year.

\begin{tabular}{|c|c|c|c|c|}
\hline \multirow{3}{*}{ Independent variables } & \multicolumn{4}{|c|}{ Dependent variables } \\
\hline & $(1)$ & $(2)$ & (3) & (4) \\
\hline & QFII & Illiq & QFII & TV \\
\hline Illiq $_{i . t-1}$ & $\begin{array}{l}-0.0011 \\
(0.0051)\end{array}$ & & & \\
\hline$T V_{i, t-1}$ & & & $\begin{array}{l}-0.0022 \\
(0.0052)\end{array}$ & \\
\hline$R \_Q F I I_{i, t-1}$ & & $\begin{array}{l}-0.0085^{*} \\
(0.0045)\end{array}$ & & $\begin{array}{c}0.0100 * * \\
(0.0045)\end{array}$ \\
\hline$S I Z E_{i, t}$ & $\begin{array}{c}0.0003 \\
(0.0131)\end{array}$ & $\begin{array}{c}-0.3168 * * * \\
(0.0122)\end{array}$ & $\begin{array}{c}0.0013 \\
(0.0131)\end{array}$ & $\begin{array}{c}0.3046 * * * \\
(0.0116)\end{array}$ \\
\hline$L E V_{i, t-1}$ & $\begin{array}{l}-0.0337 \\
(0.0484)\end{array}$ & $\begin{array}{c}-0.6046 * * * \\
(0.0454)\end{array}$ & $\begin{array}{l}-0.0324 \\
(0.0484)\end{array}$ & $\begin{array}{c}0.6229 * * * \\
(0.0449)\end{array}$ \\
\hline$V O L_{i, t}$ & $\begin{array}{c}0.0252 \\
(0.3649)\end{array}$ & $\begin{array}{c}9.5309 * * * \\
(0.4206)\end{array}$ & $\begin{array}{c}0.0585 \\
(0.3594)\end{array}$ & $\begin{array}{c}21.4262 * * * \\
(0.3942)\end{array}$ \\
\hline$N T_{i, t-1}$ & $\begin{array}{c}0.0008 \\
(0.0009)\end{array}$ & $\begin{array}{c}0.0043 * * * \\
(0.0006)\end{array}$ & $\begin{array}{c}0.0008 \\
(0.0009)\end{array}$ & $\begin{array}{c}-0.0052 * * * \\
(0.0005)\end{array}$ \\
\hline$L N P_{i, t}$ & $\begin{array}{c}0.0589 * * * \\
(0.0123)\end{array}$ & $\begin{array}{c}-0.5640 * * * \\
(0.0113)\end{array}$ & $\begin{array}{c}0.0607 * * * \\
(0.0123)\end{array}$ & $\begin{array}{c}0.4784 * * * \\
(0.0108)\end{array}$ \\
\hline$T O_{i, t}$ & $\begin{array}{l}-0.0027 \\
(0.0025)\end{array}$ & $\begin{array}{c}-0.1396 * * * \\
(0.0029)\end{array}$ & $\begin{array}{l}-0.0026 \\
(0.0025)\end{array}$ & $\begin{array}{c}0.1478 * * * \\
(0.0029)\end{array}$ \\
\hline$R O A_{i, t}$ & $\begin{array}{c}0.0008 \\
(0.0008)\end{array}$ & & $\begin{array}{c}0.0008 \\
(0.0008)\end{array}$ & \\
\hline$A G E_{i, t}$ & $\begin{array}{c}0.0124 * * \\
(0.0060)\end{array}$ & & $\begin{array}{c}0.0126 * * \\
(0.0060)\end{array}$ & \\
\hline$C O_{i, t}$ & $\begin{array}{l}-0.0404 \\
(0.1278)\end{array}$ & & $\begin{array}{l}-0.0466 \\
(0.1256)\end{array}$ & \\
\hline State & Yes & Yes & Yes & Yes \\
\hline Time dummy & Yes & Yes & Yes & Yes \\
\hline Industry dummy & Yes & Yes & Yes & Yes \\
\hline$N$ & 63592 & 63592 & 63594 & 63594 \\
\hline $\operatorname{adj} . R^{2}$ & 0.004 & 0.806 & 0.004 & 0.831 \\
\hline$F$ & 2.7906 & 2185.1637 & 2.8181 & 2653.1149 \\
\hline
\end{tabular}

TABLE VII. ENDOGENEITY TEST

Standard errors in parentheses $(* \mathrm{p}<0.1, * * \mathrm{p}<0.05, * * * \mathrm{p}<0.01)$

We find that the coefficient estimates on R_QFII, in column 2 for the Illiquidity (Illiq) and in column 4 for the trading volume (TV) are not statistically different from zero. These results suggest that our findings about the relationship between the QFII ownership and liquidity do not influenced by endogeneity bias.

\subsection{First difference model}

The panel model in the main regression model (table 4) is estimated as the first difference, and the results are reported in table 8 . These results further confirm our previous finding that there is a positive correlation between foreign institution ownership and liquidity. 
TABLE VIII. FIRST DIFFERENCE MODEL

\begin{tabular}{|c|c|c|}
\hline \multirow{3}{*}{$\begin{array}{l}\text { Independent } \\
\text { variables }\end{array}$} & \multicolumn{2}{|c|}{ Dependent variables } \\
\hline & (1) & $(2)$ \\
\hline & $\Delta \mathrm{Illiq}$ & $\Delta \mathrm{TV}$ \\
\hline \multirow[t]{2}{*}{$\Delta Q F I I_{i, t-1}$} & $-0.0004 * *$ & 0.0001 \\
\hline & $(0.0002)$ & $(0.0002)$ \\
\hline \multirow{2}{*}{$\Delta D I_{i, t-1}$} & $-0.0063 * * *$ & $-0.0107 * * *$ \\
\hline & $(0.0020)$ & $(0.0021)$ \\
\hline \multirow[t]{2}{*}{$\triangle S I Z E_{i, t-1}$} & -0.0011 & 0.0008 \\
\hline & $(0.0007)$ & $(0.0007)$ \\
\hline \multirow[t]{2}{*}{$\triangle L E V_{i, t-1}$} & -0.0006 & -0.0023 \\
\hline & $(0.0027)$ & $(0.0025)$ \\
\hline \multirow[t]{2}{*}{$\triangle V O L_{i, t}$} & $-0.1135 * *$ & 0.0243 \\
\hline & $(0.0500)$ & $(0.0159)$ \\
\hline \multirow[t]{2}{*}{$\Delta N T_{i, t-1}$} & $-0.0005 * * *$ & $-0.0007 * * *$ \\
\hline & $(0.0001)$ & $(0.0000)$ \\
\hline \multirow[t]{2}{*}{$\Delta L N P_{i, t}$} & $0.0305 * * *$ & $0.0320 * * *$ \\
\hline & $(0.0006)$ & $(0.0007)$ \\
\hline \multirow[t]{2}{*}{$\Delta T O_{i, t}$} & $0.0067 * * *$ & $0.0115 * * *$ \\
\hline & $(0.0002)$ & $(0.0003)$ \\
\hline State & Yes & Yes \\
\hline Time dummy & Yes & Yes \\
\hline$N$ & 47532 & 47532 \\
\hline $\operatorname{adj} . R^{2}$ & 0.459 & 0.614 \\
\hline$F$ & 1323.6975 & 1420.5827 \\
\hline
\end{tabular}

Standard errors in parentheses $(* \mathrm{p}<0.1, * * \mathrm{p}<0.05, * * * \mathrm{p}<0.01)$

Compared with the level estimation of the same variable, the estimate of the coefficient of illiquidity change of foreign ownership is smaller. The economic implication is that the shorter-term net purchases of the foreign institutions have a much smaller impact on the liquidity than the changes in their longer-term holdings presumably governed by their longer-term strategic requirements. However, even if our first difference regression results are consistent with our horizontal regression results, the level of statistical significance of illiquidity and trading volume in the first difference regression will be greatly reduced. A reasonable explanation for the decrease in numbers and statistical significance is that many companies' QFII ownership shows only limited changes over time, but there are large changes between companies. Then, adopting the first difference can greatly reduce the variation of the cross section and only keep the short-term time series information. Use this time series information to identify correlation coefficients in econometric models.

\section{ADDITIONAL ROBUSTNESS CHECKS}

Table 9 shows the panel regressions of the Illiquidity (Illiq) and the trading volume (TV) on the QFII ownership. The sample 1 period is from 2004Q3 to 2007Q4. The sample 2 period is from 2008Q1 to 2015Q1 and sample 3 is defined from 2016Q1 to 2019Q1.

TABLE IX. INFLUENCE OF THE MARKET SHOCK

\begin{tabular}{|c|c|c|c|c|c|c|}
\hline \multirow{3}{*}{$\begin{array}{l}\text { Independent } \\
\text { variables }\end{array}$} & 2004Q3-2008Q4 & \multicolumn{4}{|c|}{ Dependent variables } & 2016Q1-2019Q1 \\
\hline & (1) & (2) & (3) & (4) & $(5)$ & (6) \\
\hline & Illiq & TV & Illiq & TV & Illiq & TV \\
\hline \multirow[t]{2}{*}{$Q F I I_{i, t-1}$} & -0.0032 & $0.0156^{* *}$ & $0.0128^{*}$ & $-0.0123^{*}$ & $-0.0228 * * *$ & $0.0248 * * *$ \\
\hline & $(0.0063)$ & $(0.0063)$ & $(0.0069)$ & $(0.0066)$ & $(0.0075)$ & $(0.0066)$ \\
\hline \multirow[t]{2}{*}{$D I_{i, t-1}$} & $-.4725 * * *$ & $0.3195 * * *$ & & & $-0.9199 * * *$ & $0.7727 * * *$ \\
\hline & $(0.0948)$ & $(0.0923)$ & & & $(0.1491)$ & $(0.1247)$ \\
\hline \multirow[t]{2}{*}{$S I Z E_{i, t}$} & $-.1694 * * *$ & $0.2133 * * *$ & $-.3475 * * *$ & $0.3145^{* * *}$ & $-0.1024 * * *$ & $0.0431 * *$ \\
\hline & $(0.0209)$ & $(0.0233)$ & $(0.0177)$ & $(0.0179)$ & $(0.0353)$ & $(0.0190)$ \\
\hline \multirow[t]{2}{*}{$L E V_{i, t-1}$} & $0.1528^{*}$ & -0.0692 & $-.7854 * * *$ & $0.9211 * * *$ & -0.0964 & 0.1014 \\
\hline & $(0.0838)$ & $(0.0896)$ & $(0.0604)$ & $(0.0667)$ & $(0.1093)$ & $(0.0810)$ \\
\hline \multirow[t]{2}{*}{$V O L_{i, t}$} & $3.4516^{* *}$ & $-1.6049 *$ & $0.7778 * *$ & $0.8626^{* *}$ & $23.3099 * * *$ & $12.1785^{* * *}$ \\
\hline & $(1.3420)$ & $(0.9085)$ & $(0.3146)$ & $(0.3787)$ & $(0.6993)$ & $(0.7334)$ \\
\hline \multirow[t]{2}{*}{$N T_{i, t-1}$} & $0.0031 * * *$ & $-.0036 * * *$ & $0.0087 * * *$ & $-.0133 * * *$ & $0.0248 * * *$ & $-0.0294 * * *$ \\
\hline & $(0.0005)$ & $(0.0005)$ & $(0.0007)$ & $(0.0007)$ & $(0.0044)$ & $(0.0067)$ \\
\hline
\end{tabular}




\begin{tabular}{lcccccc}
$L N P_{i, t}$ & $-.7110^{* * *}$ & $0.5880^{* * *}$ & $-.5570^{* * *}$ & $0.5700^{* * *}$ & $-0.5719^{* * *}$ & $0.5209^{* * *}$ \\
& $(0.0150)$ & $(0.0137)$ & $(0.0140)$ & $(0.0145)$ & $(0.0312)$ & $(0.0290)$ \\
$T O_{i, t}$ & $-.2233^{* * *}$ & $0.2926^{* * *}$ & $-.1012^{* * *}$ & $0.1586^{* * *}$ & $-0.1564^{* * *}$ & $0.1670^{* * *}$ \\
& $(0.0150)$ & $(0.0161)$ & $(0.0037)$ & $(0.0046)$ & $(0.0080)$ & $(0.0080)$ \\
State & Yes & Yes & Yes & Yes & Yes & Yes \\
\hline$N$ & 11078 & 11078 & 42860 & 42860 & 10716 & 10716 \\
adj. $R^{2}$ & 0.815 & 0.872 & 0.538 & 0.704 & 0.481 & 0.674 \\
$F$ & 1423.6520 & 2073.7114 & 1858.7740 & 3670.5704 & 234.1961 & 552.7097 \\
\hline
\end{tabular}

Standard errors in parentheses $\left(* \mathrm{p}<0.1,{ }^{* *} \mathrm{p}<0.05,{ }^{* * *} \mathrm{p}<0.01\right)$

Like many developing countries, China enjoys a booming stock market. However, the Chinese stock market was not immune to the Global Financial Crisis during 2007-2008 and the market shock in 2015. The stock market in China essentially crashes. In addition, the total assets held by foreign institutions fell sharply from early 2008 to the end of the year, and then rose again to pre-crisis levels in the second half of 2009. Based on the behavioral changes of foreign institutions at the beginning of 2008 (presumably caused by the global financial crisis), we conduct a sub-cycle analysis using panel regression in the main regression, as shown in table 4, to investigate the link between QFII ownership and liquidity to see whether it changes over time. These samples are divided into two sub-samples: sample 1, defined as 2004Q3-2007Q4; sample 2 is defined as 2008Q1-2015Q4, and sample 3 is defined as 2016Q1-2019Q1. The results are reported in table 8 .

We find that the association between the participation of QFIIs and the illiquidity remains strong before 2008 and after 2015, yielding a negative link between the ownership and the illiquidity and a positive link between the ownership and the trading volume. The coefficients for the illiquidity and trading volume are more statistically significant and greater after 2015 than before 2008, implying that QFII plays a more and more important role in recent market-oriented reform. As to the domestic institutions, the sub-period results are again consistent with the full sample results.

\section{CONCLUSION}

With the continuous opening of the capital market and the entry of foreign capital into the stock market, there are many controversies about the consequences, which have become a hot topic in the academia. This paper employs a unique setting for the limited participation of qualified foreign institutional investors (QFIIs) in the A-share market in China and examines how these impacts on stock liquidity in emerging markets.

Contrary to the findings in the literature, our results reveal that greater foreign institutional participation is positively associated with the stock market liquidity. This positive relationship operates mainly through promoting trade activities by increasing trading volume. We also find that there exists heterogeneity in the effect of the QFII ownership on different size of firms. The improvement in liquidity is more significant in small firms compared to large firms. Our findings are robust to endogeneity and the possible influence of the stock market shock, industry effects and the stock exchange. Moreover, the liquidity improving effects of QFII are even stronger when the analysis is performed on a subsample of QFII firms.

\section{ACKNOWLEDGEMENT}

First and foremost, I would like to show my deepest gratitude to my teachers and professors in my university, who have provided me with valuable guidance in every stage of the writing of this thesis. Further, I would like to thank all my friends and roommates for their encouragement and support. Without all their enlightening instruction and impressive kindness, I could not have completed my thesis.

\section{REFERENCES}

1. K. A. Froot, P. G. J. O'Connell, M. S. Seasholes, The Portfolio Flows of International Investors I, Journal of Financial Economics, 2001, vol.59(2), pp. 151-193.

2. L. Sun, L. Lin, Empirical Analysis of QFII Investment in Mainland China Securities Market, Financial Research, 2006, vol.7, pp. 123-133.

3. Y. Tong, G. Wang, Shareholdings of overseas institutional investors, company performance and stock market quality, Accounting and Economic Studies, 2015, vol.6, pp. 101-110.

4. S. J. Grossman, On the Impossibility of Informationally Efficient Markets, American Economic Review, 1980, vol.70(3).

5. K. H. Bae, W. Bailey, C. X. Mao, Stock market liberalization and the information environment, Journal of International Money and Finance, 2006, vol.25(3), pp. 0-428.

6. T. Opler, L. Pinkowitz, R. Stulz, R. Williamson, The determinants and implications of corporate cash holdings, Journal of Financial Economics, 1999, vol.52(1), pp. 3-46.

7. M. Ding, B. Nilsson, S. Suardi, Foreign Institutional Investment, Ownership, and Liquidity: Real and Informational Frictions, Financial Review, 2017, vol.52(1), pp. 101-144.

8. Y. Amihud, H. Mendelson, L. H. Pedersen, Market Liquidity: Illiquidity and Stock Returns: CrossSection and Time-Series Effects, Journal of Financial Markets, 2002, vol.5(1), pp. 31-56.

9. H. Mendelson, T. I. Tunca, Strategic Trading, Liquidity, and Information Acquisition, Review of Financial Studies, 2004, vol.17(2), pp. 295-337. 
10. H. R. Stoll, R. E. Whaley, Transaction costs and the small firm effect, Journal of Financial Economics, 1983, vol.12(1), pp. 57-79.

11. T. Chordia, A. Subrahmanyam, R. Roll, Market Liquidity and Trading Activity, Journal of Finance, 2001, vol.56(2), pp. 501-530.

12. K. H. Chung, J. Elder, J. C. Kim, Corporate Governance and Liquidity, Journal of Financial and Quantitative Analysis, 2010, vol.45(02), pp. 265-291. 